\title{
PERFECTION OF PAPER TRANSPORTATION SETTINGS TO GET PROPERTIES ON MACHINE KOMORI LITHRONE G40
}

\section{KESEMPURNAAN PENYETELAN TRANSPORTASI KERTAS UNTUK MEMPEROLEH KETEPATAN CETAK PADA MESIN KOMORI LITHRONE G40}

\author{
Widya Retno Wulan ${ }^{a^{*}}$, Soebardianto ${ }^{\mathrm{a}}$ Heni $^{\mathrm{a}}$ \\ ${ }^{a}$ Teknik Grafika, Politeknik Negeri Media Kreatif, Indonesia \\ *Email: widyaretnowulan@gmail.com
}

\begin{abstract}
The perfection of the paper transportation settings raised in the Final Project work aims to achieve print accuracy, the benchmark for print accuracy is the achievement of perfection of print ink stacks on the printed results guided by the register point / print mark. Overview of the need for paper transport settings so that the printing process can run smoothly. In making this final project, the author uses a descriptive method, namely a method that explains and explains about paper transportation. The formulation of the problem that is taken in this final project is how to set up paper transportation, problems that arise during paper transportation, and solutions that can be done to overcome these problems. In this paper, the authors use literature review, field observations, and interviews related to data. From the results of these observations, it can be shown that the problems that occur at the time are caused by paper transportation settings that are not in accordance with standard work procedures. Suggestions put forward by the authors need to apply standardization of settings and provision of training for each operator who works
\end{abstract}

\section{Keywords - Paper transport, print accuracy, tuning}

\begin{abstract}
Abstrak - Kesempurnaan penyetelan transportasi kertas yang diangkat dalam karya Tugas Akhir bertujuan untuk mencapai ketepatan cetak, tolak ukur untuk ketepatan cetak adalah tercapainya kesempurnaan tumpukan tinta cetak pada hasil cetakan yang berpedoman pada titik register/tanda tepat cetak. Perlunya tinjauan tentang penyetelan transportasi kertas agar proses pencetakan dapat berjalan lancar. Dalam pembuatan karya Tugas Akhir ini, penulis menggunakan metode deskriptif yaitu metode penulisan yang bersifat menjelaskan dan memaparkan tentang transportasi kertas. Rumusan masalah yang diambil dalam Tugas Akhir ini yaitu cara penyetelan transportasi kertas, masalah yang timbul selama transportasi kertas
\end{abstract}


berlangsung, dan solusi yang dapat dilakukan untuk mengatasi masalah tersebut. Pada karya tulis ini penulis menggunakan tinjauan pustaka, observasi lapangan, dan wawancara terkait pengumpulan data. Dari hasil pengamatan tersebut dapat disimpulkan bahwa permasalahan yang terjadi pada saat produksi berlangsung disebabkan oleh penyetelan transportasi kertas yang tidak sesuai dengan standar prosedur kerja. Saran yang diajukan penulis ialah perlunya diterapkan standarisasi penyetelan dan pengadaan pelatihan pada tiap operator yang beke.

\section{Kata Kunci- Transportasi kertas, ketepatan cetak, penyetelan}

\section{PENDAHULUAN}

Ilmu grafika sangat berperan penting dalam kehidupan manusia sehari-hari. Mulai dari produk grafika yang bersifat komersial, seperti kalender, majalah, tabloid, koran, buku, kemasan produk makanan dan minuman. Akan tetapi ada juga produk grafika yang bersifat non komersial seperti akta kelahiran, KTP, kartu keluarga, ijazah, surat kematian, sertifikat tanah, dan masih banyak lagi. Semua produk grafika itu tidak dapat dipisahkan oleh kehidupan manusia

Pada bagian cetak, mengerjakan proses pencetakan dengan menggunakan teknik cetak datar (cetak ofset). Dalam cetak ofset perlu diperhatikan pada tiap unitnya, mulai dari unit pemasukan, sampai unit pengeluaran, dalam upaya meningkatkan kualitas cetak maka harus memperhatikan keseimbangan antara air dan tinta. Keseimbangan akan mudah didapat apabila transportasi kertas lancar.

Kelancaran pada saat mencetak berpengaruh dari kesempurnaan penyetelan transportasi kertas yang akan mempengaruhi kestabilan jalannya kertas. Penyetelan perangkat-perangkat yang ada pada unit pemasukan merupakan hal yang sangat diperlukan untuk mendapatkan kelancaran jalannya kertas. Untuk itu adanya pemahaman tentang kesempurnaan penyetelan pada transportasi kertas untuk kelancaran lajunya kertas serta pengendaliannya sangat dibutuhkan. Demi mencapai kelancaran transportasi kertas, ada beberapa hal yang harus diperhatikan yaitu penyetelan komponen unit pemasukan seperti : kekuatan angin penghisap, kekuatan angin penghembus, ketinggian meja penumpukan kertas, meja aparat, double sheet detector, serta lainnya, serta penyetelan alur jalan kertas lainnya mulai dari awal masuk kertas hingga kertas keluar pada unit pengeluaran dan sudah menjadi suatu barang cetakan dengan ketepatan cetak yang baik. Kertas yang akan digunakan juga berpengaruh pada penyetelan yang akan dilakukan. 
Maka dari itu pemahaman tentang penyetelan unit pemasukan sangat diperlukan, karena berperan sebagai acuan dasar untuk mencapai kestabilan transportasi kertas pada saat pencetakan, yang kemudian akan dilanjutkan dengan penyetelan dari tiap-tiap unit selanjutnya hingga kertas mencapai unit pengeluaran jadi di kelompokan masalah yang akan diselesaikan adalah bagaimana penyetelan transportasi kertas pada mesin KOMORI LITHRONE G40 agar kertas berjalan dengan lancar selama proses pencetakan berlangsung, bagaimana masalah yang timbul akibat penyetelan transportasi kertas yang tidak sempurna pada mesin cetak KOMORI LITHRONE G40, bagaimana cara mengatasi masalah yang diakibatkan dari penyetelan transportasi kertas yang tidak sempurna pada mesin KOMORI LITHRONE G40

\section{METODE PENELITIAN}

Metode penelitian yang digunakan dalam adalah metode penulisan deskriptif, yaitu metode yang bersifat menjelaskan. Penulis menggunakan beberapa metode untuk memperoleh data dan informasi sebagai referensi untuk memecahkan permasalahan yang ada dalam pembuatan karya Tugas Akhir ini. Berikut teknik pengumpulan data yang digunakan, yaitu :

Tinjauan pustaka dengan metode ini, penulis mencari dan mengumpulkan data yang bersifat teoritis dan mempelajari beberapa materi pustaka, seperti buku-buku, makalah, internet, artikel dan materi kuliah yang bersangkutan dengan materi yang dibahas. Yaitu mengenai Sejarah Teknik Cetak Ofset Litografi atau lithography berasal dari kata lithos yang berarti "batu", dan graphy/graphyn yang berarti "menulis". Jadi lithography berarti menulis di atas batu atau mencetak dengan batu. Karena antara bagian yang tidak mencetak dengan bagian mencetak pada acuan sama rata/datar, maka proses mencetak dengan batu itu juga disebut cetak datar. Yang menemukan lithography atau cetak datar dengan batu adalah Alois Senefelder. Kemudian ia menulis karyanya di atas tembaga yang dilapisi lilin, kemudian dietsa (diberi larutan asam hingga asam itu menggogos lapisan pelat yang tidak tertutup oleh lilin karena goresan jarum waktu menulis) Berdasarkan cara memasukkan material kertas yang akan dicetak, mesin cetak dapat dibagi menjadi 2, yaitu :

a. Cetak ofset lembaran (sheetfed), yaitu mesin cetak yang pada unit pemasukannya menggunakan material kertas berbentuk lembaran

b. Cetak ofset gulungan (web fed), yaitu mesin cetak yang pada unit pemasukannya menggunakan material kertas berbentuk gulungan 
Konstruksi mesin cetak ofset yang terdiri dari lima bagian unit utama, yaitu :

1. Unit Pemasukan (Feeder Unit)Unit pemasukan kertasberfungsi menghantarkan kertas lembaran demi lembaran masukke dalamperalatan pencetakan. Untuk mendapatkan pemasukan kertasyang tepat dalam kecepatan tinggi, maka seluruhkomponen pemasukan dan pengeluaran harus berfungsi dan bekerjadengan baik untuk mendapatkan kertas pada posisi kertasyangtepat.

2. Unit Penintaan (Inking Unit)Unit penintaan memberikan atau menyalurkan lapisan tinta meratadan halus ke permukaan pelat cetak secara terus menerus dan merata,susunan rol sangat mempengaruhi mutu hasil cetakan. Sistem penintaanpada mesin cetak ofset terdiri dari : bak tinta,rol bak tinta, rol jilat tinta,rol distribusi tinta, rol pelat.

3. Unit Pembasah (Dampening Unit)Unit pembasahan berfungsi untuk memberikan pembasahan padapermukaan pelat cetakyang dilakukan secara terus menerus selama proses pencetakan dan dalam jumlahyang tepat. Susunan rol pembasah dapatmempengaruhi proses pembasahan permukaanpelat. Unit pembasahan terdapat rol-rol distribusi air, rol perantara dan rol pelat. Air pembasah iniberfungsi memberikan air pada bagianyang tidak tercetak agar tidakmenarik tinta.

4. Unit Pencetakan (Printing Unit)Unit pencetakan adalah suatu prosesalih gambar yang terjadi pada mesin cetak ofset yang terdiri dari tiga silinder utamayaitu : silinder pelat,silinder kain karet, silinder tekan. Tiga siliner inilahyang menggambarkanprinsip dasar cetak ofsetyaitu proses alih gambar dari silinder kain karetke permukaan kertas dengan menggunakan silinder silinder tekan sebagaipenekan danyang terpenting proses terjadinya image di silinder pelat yaitu bagian gambar menarik tinta

Kesempurnaan transportasi kertas untuk memperoleh ketepatan Cetak. Ketepatan cetak mencakup tentang keseragaman penumpukan pada saat pencetakan antara bidang gambar dengan bidang gambar lainnya, karena pada saat pencetakan menggunakan hasil cetakan full color diperlukan ketepatan dalam penumpukan antara tiap bidang bergambarnya. Apabila pada saat pencetakan full color penumpukan bidang gambar tidak sama rata maka akan menghasilkan gambar pada hasil cetakan menjadi berbayang, atau 
tidak fokus, sulit didapatkan warna yang ingin dicapai, serta membuat gambar menjadi terlihat tidak presisi.

Untuk mendapatkan ketepatan cetak yang baik maka perlu dilakukan pengendalian terhadap ketepatan cetak. Yang dimaksud dengan pengendalian terhadap ketepatan cetak adalah suatu aktifitas yang dilakukan untuk menjaga agar tumpukan dari tiap gambar pada tiap pencetakan selalu presisi.

Berbagai kegiatan yang berhubungan dengan kegiatan pengendalian ketepatan cetak diantaranya :

a. Mengecek kembali ketepatan register dari order yang akan dibuat dari pemesan.

b. Memperhatikan ketepatan register pada saat pembuatan plate.

c. Pada saat pelubangan plate (punching) dilakukan dengan mengikuti tanda pas kris.

d. Memastikan kesesuaian penyetelan unit pemasukan dengan standar yang sudah ditetapkan.

e. Memastikan pada saat penumpukan kertas di meja penumpukan arah serat kertas sudah benar.

Tujuan dan fungsi pengendalian ketepatan cetak, pelaksanaan pengendalian ketepatan cetak memiliki beberapa tujuan dan fungsi, diantaranya : a. Untuk meningkatkan kepuasan konsumen.

b. Untuk menekan jumlah produk yang cacat.

c. Untuk mendapatkan hasil cetakan yang baik.

d. Untuk mengontrol waktu (agar order dapat diselesaikan tepat waktu).

e. Untuk menekan laba perusahaan.

Hal-hal yang Berpengaruh terhadap Ketepatan Cetak yang baik ketepatan cetak adalah ketepatan penumpukan antara gambar satu dengan warna lainnya, apabila penumpukan gambar tidak pas antara satu dengan lainnya maka disebut dengan miss register. Ketepatan cetak dipengaruhi beberapa hal, seperti :

a. Pengaruh dari kelancaran transportasi kertas

Pada saat produksi berlangsung, penyetelan transportasi kertas yang kurang baik dapat menghambat jalannya mesin maupun hasil dari ketepatan cetak. Maka dari itu posisi tumpukan kertas harus rapih dengan arah serat yang tepat pada meja penumpukan. Penyetelan komponen unit pemasukanpun harus seimbang dan sesuai dengan material kertas yang akan digunakan mencakup ukuran kertas, gramatur kertas, dan jenis kertas yang akan digunakan, dan kecepatan mesin yang akan digunakan.

b. Pengaruh dari pelat cetak 
Pelat yang akan dipergunakan juga dapat berpengaruh terhadap ketepatan cetak, apabila pelat yang akan digunakan titik register tidak pas antara satu bidang gambar ke bidang gambar lainnya maka akan menjadi miss register, operator harus memperhatikan ketepatan pas kruis dan tanda tepat cetak saat pelubangan pelat. Apabila pada saat pelubangan pelat miring, maka ketepatan register akan menjadi sulit untuk dicapai dan pada saat pemasangan pelat posisi pelat harus sesuai dengan pin atau pas digaris tengah.

c. Pengaruh tekanan cetak

Tekanan cetak harus sesuai dengan gramatur kertas yang akan digunakan, apabila kertas yang digunakan tipis maka tekanan cetak harus ditambah, dan jika kertas yang digunakan tebal maka tekanan cetak harus dikurangi karena jika tekanan cetak kurang pada saat pencetakan memungkinkan kertas untuk menjadi melengkung, dan bila tekanan cetak terlalug. berlebih dapat membuat kertas mengembang dan berakibat misregister pada hasil cetakan.

d. Pengaruh bahan cetakan

Suhu udara tempat penyimpanan kertas dapat mempengaruhi pengembangan kertas, apabila suhu udara terlalu lembab juga dapat membuat kertas menjadi bergelombang. Kertas yang mengembang dapat membuat register sulit di capai dan kertas bergelombang juga dapat membuat transportasi kertas tidak lancar dan registerpun menjadi tidak sempurna.

e. Arah serat kertas

Pada saat memasukkan kertas pada meja penumpukan kertas, posisi arah serat kertas harus vertikal atau searah dengan putaran silinder. Apabila arah serat kertas pada saat pemasukan kertas tidak searah dengan arah putaran silinder maka akan membuat tinta cetak menjadi mengembang ke samping yang akan membuat register pada hasil cetakan tidak akan dapat dicapai.

f. Roda aparat dan karet penghantar kertas (sheet belt)

Keseimbangan antara kedua roda aparat harus seimbang, apabila kedua roda aparat tidak seimbang (salah satu roda aparat terlalu menekan kertas) akan membuat kertas menjadi tertahan dan jalannya kertas menjadi miring sehingga mengakibatkan register tidak dapat dicapai.

Kain karet

Apabila pemasangan kain karet tidak kencang atau longgar, maka akan membuat permukaan kain karet menjadi bergelombang yang akan mengakibatkan pengalihan gambar menjadi tidak sempurna karena gambar akan terlihat berbayang dan ketepatan register sulit dicapai.

Berikut adalah contoh image yang tidak register : 


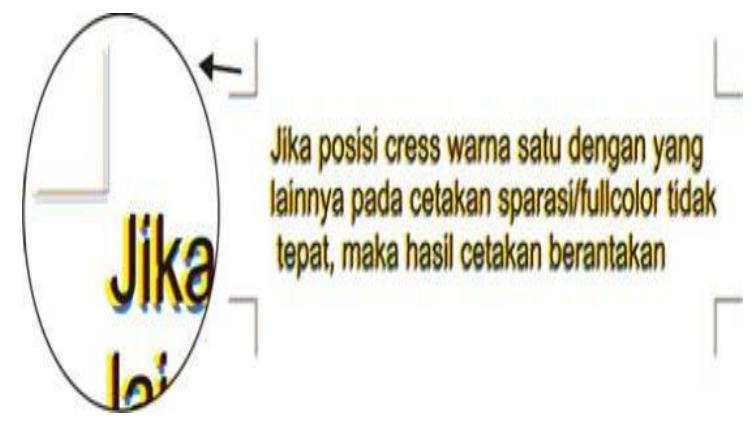

\section{a. Ruangan Produksi}

1. Sheetfed Press

Dua unit Mitsubishi D3000LS- 4C, tiga unit KBA Rapida 105 - 4C, satu unit KBA Rapida 74 - 4C, satu unit Heidelberg Speedmaster 102 - 2C, dan dua unit KBA Rapida 106 - 8C

Gambar 1. Cetakan yang tidak register
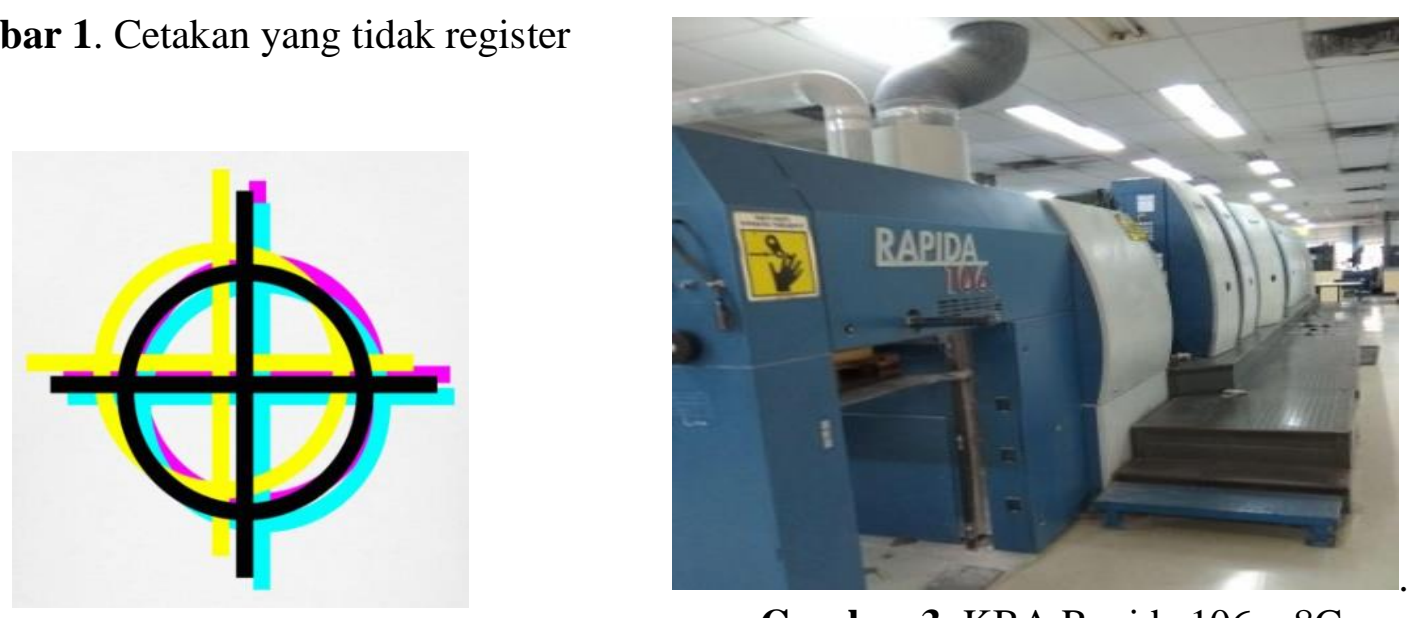

Gambar 3. KBA Rapida 106 - 8C

Gambar 2. Register mark yang tidak menumpuk dengan sempurna

2. Web Press

Dua unit Mitsubishi D16-Z, dan 1 unit Solna D30.

Observasi lapangan Penulis

\section{b. Ruang Penyelesaian}

\section{Perfect binder}

melakukan observasi atau pengamatan yang dilakukan dengan cara terjun langsung ke lapangan di PT. Gramedia Printing Cikarang, sesuai dengan judul yang diangkat oleh peneliti. dengan cara ini penulis dapat mengumpulkan dan melihat serta mempraktikan secara langsung cara penyetelan transportasi kertas pada mesin KOMORI LITHRONE G40.dan diskripsi pekerjaannya peralatan yang digunakan antara lain

Dua unit Muller Martini Acoro A7

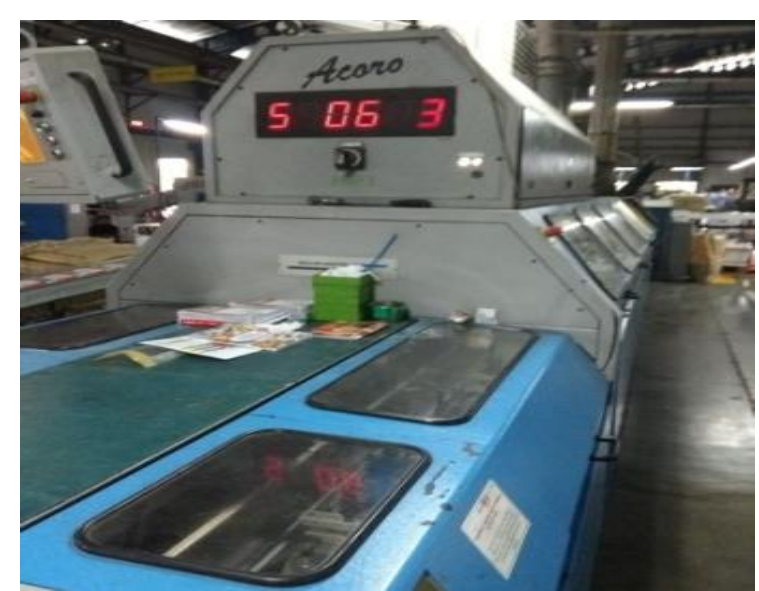

Gambar 4. Muller Martini Acoro A7 


\section{Saddle stitcher}

Satu unit Muller Martini Bravo Plus, satu unit Heidelberg ST350, dan satu unit Muller Martini 335

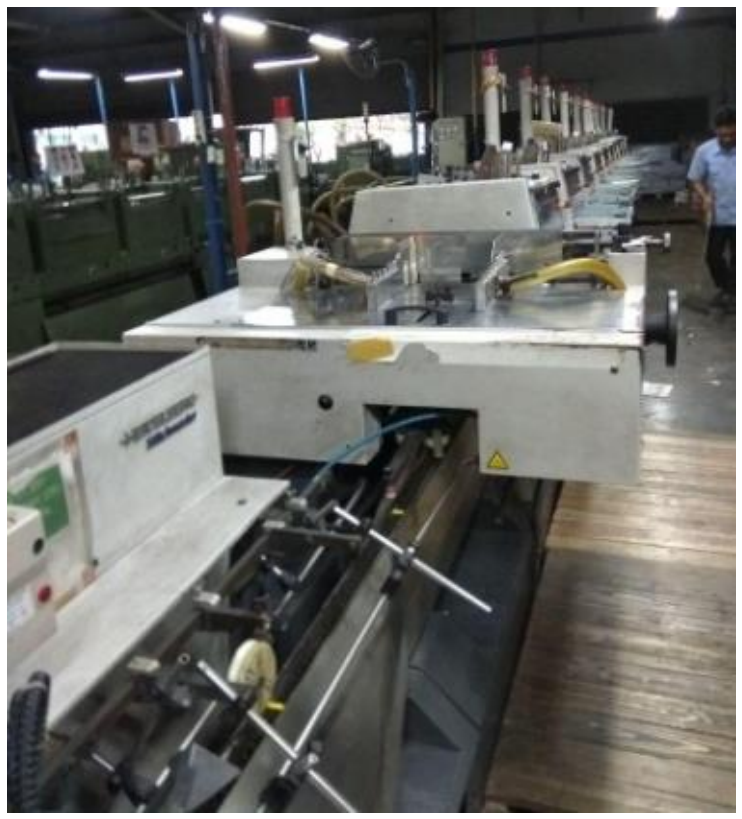

Gambar 5. Muller Martini Bravo Plus

\section{Cutting \& folding machines}

Dua unit Polar 137X, Itoh 132FC, satu unit Wohlenberg MCS, tujuh unit Heidelberg Stahlfolder, dua unit MBO folder

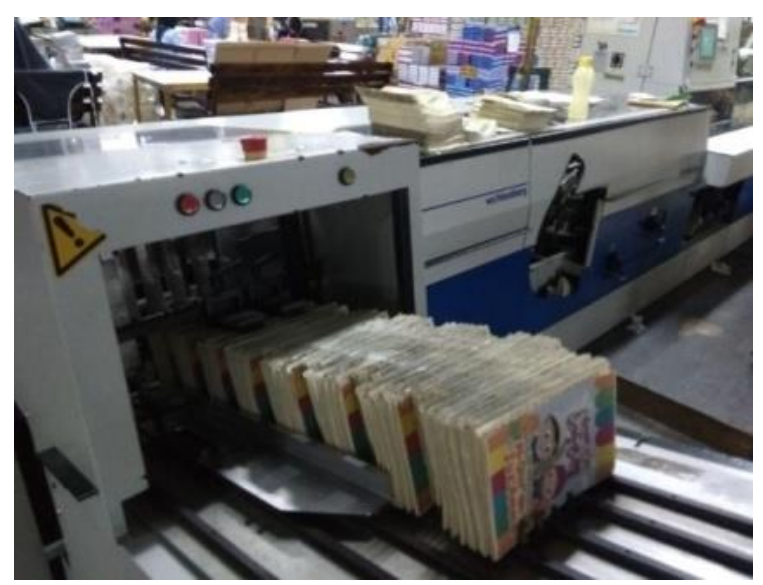

Gambar 6. Wohlenberg MCS

\section{Hardcover line}

Dua unit Muller Martini Ventura sewing machine, satu unit Hurauf Universal R Casemaker, satu unit Muller Martini Collibri + Diamant bookline

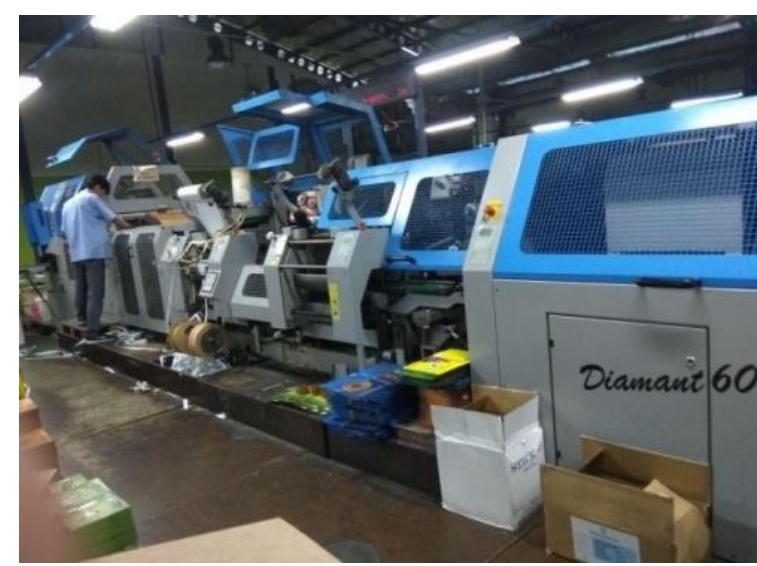

Gambar 7. Diamant bookline

Dengan spesifikasi mesin cetak
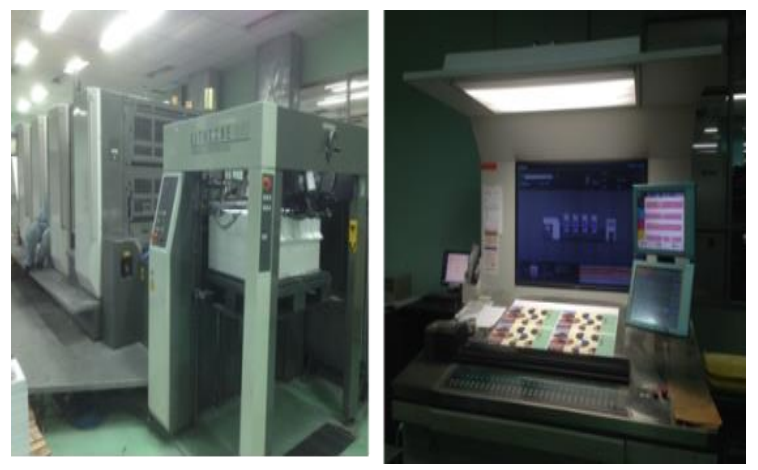

Gambar 8. Komori Lithrone G40 Dan Unit Konsul

\section{Ukuran kertas}

Minimal : $36 \times 52 \mathrm{~cm}$

Maksimal : $72 \times 103 \mathrm{~cm}$

\section{Kecepatan mesin}

Minimal : $3.500 \mathrm{Rph}$

Maksimal : $13.000 \mathrm{Rph}$

\section{Ketebalan kertas}

Minimal : $0,04 \mathrm{~mm}$

Maksimal : $0,08 \mathrm{~mm}$

Area cetak maksimal : $71 \times 102 \mathrm{~cm}$

Ukuran plate : $80 \times 103 \mathrm{~cm}$ 
Ukuran kain karet $\quad$ : 92 x $104 \mathrm{~cm}$

Kemampuan menampung kertas

pemasukan

$: 1.075 \mathrm{~kg}$

pengeluaran

$: 1.075 \mathrm{~kg}$

\section{c. Alur transportasi kertas}

1. Unit pemasukan (feeder unit) akan menghembuskan angin melalui pipapipa angin pengembus.

2. Pipa penghisap (pick up sucker) mulai menghisap kertas pada tumpukan kertas satu persatu.

3. Pipa penghantar (forwarder sucker) akan menarik dan mendorong kertas menuju meja aparat.

4. Pada meja aparat, kertas akan dibawa oleh ban karet berjalan (sheet belt).

5. Pada ujung bawah meja aparat, kertas akan masuk pada celah sheet smoother dan tertahan oleh penepat depan (front lay)

6. Setelah tertahan tertahan penepat depan (front lay) kertaas akan di tarik oleh penepat samping (side lay). Arah tarikan sesuai kebutuhan GS (gear sie) atau OS operator side) yang dipakai pada saat pencetakan.

7. Pada saat penepat depan (front lay) terbuka, bagian kepala kertas akan diambil oleh gripper transfer dan diteruskan pada unit pencetakan 1 .
8. Dari unit pencetakan 1 , kertas akan dilanjutkan ke unit pencetakan 2, 3 dan 4 menggunakan silinder transfer.

9. Setelah unit cetak 4, kertas akan diteruskan oleh gripper swing arm menuju unit pengeluaran (delivery unit.)

10. Dari gripper swing arm kertas akan dilepaskan satu persatu sesuai timing yang diatur oleh cam opening gripper.

11. Saat dilepaskan oleh gripper swing arm, bagian ekor kertas akan dihisap oleh suction wheel sehingga terjadi pengereman.

12. Agar bagian ekor kertas tetap rapih, suction wheel akan berputar untuk melempar bagian ekor kertas.

13. Setelah kertas dilepaskan oleh gripper swing arm, kertas akan didirong oleh angin dari kipas dan angin pipa yang terletak di atas delivery.

14. Ketika kertas sudah terjatuh pada meja pengeluaran, kertas akan dirapihkan oleh jogger belakang dan jogger samping.

Dalam upaya mencapai ketepatan cetak yang maksimal pada mesin cetak KOMORI LITHRONE G40 maka kita harus memperhatikan kestabilan jalannya kertas 50 selama pencetakan berlangsung. Register 
hanya akan dicapai apabila ke 4 warna cyan, magenta, yellow, black dapat menumpuk dengan sempurna dan presisi. Apabila 4 warna tinta tidak menumpuk dengan sempurna akan mengakibatkan misregister yang membuat cetakan menjadi cacat. Dengan demikian ketepatan register harus dicapai dengan maksimal dengan berbagai upaya.

Penyetelan unit pemasukan yang kurang baik pada saat persiapan mesin dapat menyebabkan kendala pada saat transportasi kertas dan juga pada saat produksi cetak. Penyetelan komponen-komponen unit pemasukan yang kurang baik dapat mempengaruhi ketepatan cetak yang akan diperoleh, karena apabila transportasi kertas tidak lancar maka operator mesin cetak akan sulit mencapai ketepatan cetak yang sesuai dengan standar yang telah ditetapkan.

Penyetelan unit pemasukan transportasi kertas sangat mempengaruhi proses cetak dan sangat membantu proses produksi mencapai apa yang diinginkan, seperti :

\section{Kelancaran Mesin}

Pada saat produksi berlangsung pengaruh penyetelan yang kurang baik dapat menghambat kelancaran jalannya mesin salah satunya transportasi kertas yang menjadi masalah awal pada saat proses pencetakan berlangsung.

\section{Keseragaman Warna}

Keseragaman warna pada hasil cetak yang tidak sesuai dengan contoh cetak juga berpengaruh dari ketidaktepatan register saat mencetak, register yang tidak tertumpuk dengan tepat juga membuat warna yang dihasilkan pada saat pencetakan juga menjadi tidak stabil dan ketepatan warna yang diinginkan sulit dicapai.

\section{Ketepatan Register}

Ketepatan cetak atau register adalah suatu hasil cetakan 4 warna atau lebih, dimana yang warna-warnanya bertumpuk pada posisi yang sama. Register harus sangat diperhatikan pada saat proses pencetakan berlangsung, karna register amat berpengaruh terhadap warna yang akan dicapai dan kejelasan image yang akan dihasilkan, jika register tidak bertumpuk dengan tepat maka cetakan berbayang yang membuat hasil cetakan menjadi cacat. Masalah ini sering terjadi karena pada saat pelat di punch kedudukan pas kruis antara plate satu dengan pelat lainnya tidak presisi, atau bisa juga pada saat imposisi di bagian pra cetak mengalami miss register

Deskripsi Pekerjaan pada perusahaan ini adalah:

\section{a. PPIC}

1. Menerima SPK dari bagian Marketing, kemudian dilihat ada perubahan atau tidak dilihat stoknya 
2. Mengecek laporan harian dan SPK secara keseluruhan untuk menghitung bahan baku yang dipakai.

3. Membuat order bahan baku atas persetujuan pimpinan memonitor SPK sampai terealisasi pengiriman, mengecek pengiriman produk ke customer

b. Press

1. Mencetak produk

2. Mengontrol hasil cetakan agar sesuai dengan desain yang telah disepakati dengan customer.

3. Menjaga hasil cetakan agar sesuai dengan contoh warna dan order yang telah disepakati dengan customer

c. Post Press

1. Mengelem atau menjahit (menjilid) pada bagian produk tercetak sesuai dengan apa yang telah disepakati oleh customer.

2. Mengontrol hasil penjilidan agar sesuai dengan surat perintah kerja yang telah diberikan.

3. Menjaga hasil penjilidan agar selalu konsisten

Juga terdapat alur proses cetak pada PT gramedia antara lain :

1. Mengambil jadwal dan surat perintah kerja (SPK) pada department penjadwalan untuk mengetahui jadwal order yang akan dikerjakan sebelum memulai pekerjaan untuk memastikan informasi tentang order apa saja yang akan dikerjakan, serta penggunaan jenis tinta, penggunaan bahan kertas, dan ukuran kertas apa yang akan digunakan serta pada mesin apa order akan dikerjakan, dan order apa saja yang akan dikerjakan pada hari itu.

2. Mengambil contoh cetak (digital color proofing) dan pelat pada department pracetak untuk membantu operator untuk membuat acuan pada saat pencetakan berlangsung.

3. Melakukan persiapan pelat dengan membolongi (punhcing) pelat dan memasang pelat sesuai dengan pin di pelat pada mesin cetak KOMORI LITHRONE G40.

4. Mempersiapkan meterial yang akan dipergunakan, mulai dari persiapan tinta cetak, kertas untuk mencetak, dan mempersiapkan powder.

5. Melakukan persiapan mesin, mulai dari menyalakan mesin, menyetel komponenkomponen dari tiap unit, dan memeriksa PH air pembasah.

6. Melakukan cetak coba dengan menggunakan kertas aval untuk mengecek ketepatan cetak pada hasil cetakan.

7. Operator melakukan acc pada team leader, apabila cetakan tidak bermasalah maka akan langsung dilanjutkan pada pencetakan massal. 
8. Apabila cetakan mengalami kecacatan, maka dilakukan analisa penyebab masalah dan penyelesaiannya, apabila permasalahan tidak dapat diatasi maka dilakukan penggantian pelat.

9. Saat mesin melakukan pencetakan, dilakukan pengecekan bekala pada hasil cetakan tiap \pm 200 lembar cetakan diperiksa pada meja console kesetabilan warnanya dan ketepatan cetaknya.

10. Apabila pada saat pengecekan berkala ada cetakan yang bermasalah atau cacat cetak, maka akan dipisahkan dari hasil baik untuk dibuang.

11. Apabila pencetakan telah selesai, maka cetakan akan dilanjutkan pada department post press untuk dilakukan tahap lebih lanjut

c. Wawancara

Penulis melakukan wawancara dan diskusi dengan operator cetak yang berhubungan dengan objek pengamatan penulis untuk memperoleh penjelasan lebih lanjut tentang data-data yang telah terkumpul

\section{HASIL DAN PEMBAHASAN}

1. Penyetelan Transportasi Kertas pada Mesin KOMORI LITHRONE G40

Dalam sebuah proses produksi, tentunya tidak akan selalu berjalan lancar. Mengingat dalam proses cetak ofset adalah proses yang saling berkaitan antara unit ke unit, sehingga pasti akan ada masalah yang timbul disebabkan oleh salah satunya terutama pada unit pemasukan (feeder unit) yang berdampak pada ketepatan cetaknya. Penyetelan unit pemasukan (feeder unit) yang kurang baik pada saat jalannya kertas dapat menghambat kertas untuk menuju ke proses selanjutnya, dan apabila jalannya kertas sudah tidak mengalami kendala maka proses pencetakan dapat berjalan dengan lancar. Apabila trasnportasi kertas sudah berjalan dengan lancar maka dibutuhkan ketepatan cetak yang baik untuk mendapatkan hasil cetakan sesuai dengan apa yang diinginkan (contoh cetak).

Maka dari itu, berikut penulis akan memaparkan tahapan-tahapan yang harus dilakukan untuk penyetelan unit pemasukan:

\subsection{Melakukan penyetelan pada meja} konsul (meja console)

a. mengganti ukuran kertas pada mesin sesuai ukuran kertas yang akan dicetak

b. memasukkan ukuran ketebalan kertas

c. memilih anleg/penepat samping (side lay)

d. mengatur banyaknya penggunaan powder

e. menyetel ketebalan tinta yang akan dipergunakan 


\subsection{Meja penumpukan}

a. Memeriksa jenis kertas, gramatur kertas, ukuran kertas yang akan dipergunakan.

b. Memeriksa arah serat kertas.

c. Berikan angin pada kertas (mengocok/mengibas kertas) agar kertas tidak menempel dari lembar satu dengan lembar lainnya.

d. Kemudian susun kertas dengan rata di atas meja penumpukan.

e. Pastikan posisi palet tidak miring agar saat kertas dihisap posisi kertas tidak miring.

f. Lipat kertas menjadi dua bagian untuk menjadikan patokan posisi tengah kertas pada meja penumpukan.

\subsection{Mengatur Ukuran Penahan Kertas} Samping (Jogger Sheet Feeder)

a. Mengatur ukuran penahan kertas samping (jogger sheet feeder) sesuai dengan ukuran kertas yang akan dipergunakan dalam proses pencetakan.

b. Pada mesin KOMORI LITHRONE G40 pengatur penahan kertas samping (jogger sheet feeder) belum menggunakan sistem otomatis dan masih menggunakan sistem manual, yang berarti masih harus digeser secara manual oleh operator.

\subsection{Mengatur ketinggian kepala hisap (suction head)}

a. atur ketinggian permukaan kertas terhadap sheet flap $\pm 0,5-0,10 \mathrm{~cm}$.

b. putar handel (engkol) naik/turun sampai bar pada skala tinggi tumpukan menunjukkan strip ke 4-5.

c. lakukan percobaan ketinggian antara kepala hisap dengan kertas dengan menjalankan aparat kepala hisap (pick up sucker dan forwarding sucker).

d. apabila dirasa kurang maka turunkan kembali kepala hisap sampai pada saat pipa penghisap (pick up sucker) turun, ketinggian pipa penghisap dan ketinggian kertas hanya berjarak $0,5 \mathrm{~cm}$.

\subsection{Mengatur angin penghisap dan penghembus}

Penyetelan angin penghisap dan angin penghembus dilakukan dengan menggunakan baut penyetel yang ada pada alat penghisap dan penghembus. Pada mesin KOMORI LITHRONE G40, penyetelan angin belum menggunakan sistem otomatis, yang artinya masih menggunakan pengaturan manual. Kekuatan hisapan dan hembusan angin juga berpengaruh dari material yang digunakan pada saat proses pencetakan. Kekuatan hisapan dan hembusan angin harus seimbang agar jalannya kertas lancar.

\section{A. Menyetel alat penghembus pada meja penumpukan}

Alat penghembus sangat berpengaruh 
terhadap kelancaran jalannya kertas, mesin KOMORI LITHRONE G40 memiliki 8 angin penghembus, yaitu :

1. Dua di bagian samping depan.

2. Dua di bagian samping belakang.

3. Dua di bagian depan kertas untuk memisahkan tiap lembaran kertas.

4. Dua di bagian depan kertas untuk menghembuskan beberapa lembar kertas.

Untuk menyetel alat penghembus, maka yang perlu dilakukan adalah :

a. Putar baut penyetel angin penghembus samping depan ke arah kanan dengan hembusan angin yang dibutuhkan, jangan terlalu besar dan jangan terlalu kecil, atur sampai angin mampu menghembuskan kertas sekitar 15-20 lembar kertas.

b. Atur jarak antara pipa penghembus samping dengan kertas, jangan sampai membuat ujung kertas menjadi tergulung.

c. Atur angin penghembus depan sampai kertas terangkat 10-15 lembar dengan memutar baut penyetel.

d. Pastikan posisi angin penghembus depan sudah sejajar dengan kertas.

e. Atur kekuatan angin penghembus depan dengan memutar baut penyetel, pastikan angin penghembus depan hanya memisahkan satu lembar kertas untuk diangkat oleh alat penghisap.

\section{B. Menyetel alat penghisap}

Alat penghisap kertas harus seimbang dengan alat penghembus kertas, tidak boleh ada yang salah satunya lebih kuat atau lebih lemah. Alat penghisap kertas berjumlah 4 buah, yaitu :

1. Dua buah penghisap yang berfungsi untuk menghisap kertas (bekerja secara naik turun) atau biasa disebut dengan pickup sucker.

2. Dua buah penghisap yang berfungsi untuk menghantarkan kertas ke depan atau yang biasa disebut forwarding sucker.

Untuk mengatur daya hisap pada alat penghisap kertas perlu dilakukan beberapa hal, yaitu :

a. Setel ketinggian antara alat penghisap (pick up sucker) dengan permukaan tumpukan kertas $\pm 0,5 \mathrm{~cm}$.

b. Setel kekuatan hisap alat penghisap (pick up sucker) terhadap kertas dengan memutar kenop sampai sekecil mungkin tapi mampu menghisap satu lembar kertas.

c. Atur kemiringan pick up sucker dengan memutar tuas kenop yang terdapat pada komponen kepala hisap (suction head)

d. Karet vakum harus disesuaikan dengan jenis kertas yang akan di pergunakan, apabila karet vakum cacat/berlubang 
maka kekuatan penghisapan akan terganggu.

\subsection{Mengatur penepat samping (side lay)}

Lakukan penyetelan ketebalan kertas pada penepat samping (side lay) dengan menggunakan dua lembar kertas, langkah-langkah yang perlu dilakukan yaitu:

a. Memasukkan dua lembar kertas yang akan digunakan pada celah side lay

b. Kencangkan baut penyetel hingga kertas terjepit

c. Kendurkan baut penyetel hingga kertas dapat masuk antara celah side lay

d. Putar baut penyetel sampai kertas tertarik $\pm 0,5 \mathrm{~cm}$

e. Lihat apakah kertas yang tertarik sudah $0,5 \mathrm{~cm}$ atau belum selama kertas berjalan di meja aparat.

\subsection{Menyetel lidah pemisah kertas}

a. Putar baut untuk mengendurkan lidah pemisah kertas agar dapat di maju mundurkan dan dinaik turunkan.

b. Sesuaikan setelan lidah pemisah kertas hingga mencapai $\pm 0,2-0,10 \mathrm{~cm} \mathrm{ke}$ dalam kertas.

c. Sesuaikan juga lidah pemisah kertas sedemikian rupa sehingga berada \pm 0 $0,3 \mathrm{~cm}$ ditepi atas tumpukan kertas.

\subsection{Menyetel roda penghantar kertas}

a. gunakan dua lembar kertas.

b. tempatkan pada meja penghantar (meja infeed) bagian depan diratakan pada penepat depan dan ditarik pada penepat samping yang akan digunakan.

c. geser roda agar posisi roda berada di ujung belakang kertas.

d. apabila pada saat produksi posisi roda belum pas, maka geser kembali roda sampai posisi yang diinginkan.

\subsection{Menyetel Karet Penghantar Kertas (sheet belt)}

Memutar adjuster ke kanan untuk menambahkan kekuatan hisap dan ke kiri untuk mengurangi kekuatan hisap, adjuster ini berfungsi mengatur kekuatan angin penghisap pada karet penghantar.

\section{Permasalah yang Terkait pada Transportasi kertas di Mesin KOMORI LITHRONE G40}

Berikut ini merupakan masalah yang terjadi karena penyetelan di unit pemasukan (feeder unit) yang kurang baik beserta penyebabnya, yaitu :

\subsection{Lembar kertas sering terhisap ganda}

Penyebab :

a. Kurang atau terlalu besarnya angin penghembus sehingga kertas tidak terpisahkan dengan baik lembar demi lembarnya pada tumpukan kertas.

b. Lembaran kertas tidak tertahan dibawah lidah penahan kertas. 
c. Tumpukan kertas pada meja penumpukan terlalu tinggi.

d. Angin penghisap terlalu besar.

e. Kertas lengket satu dengan lainnya.

\section{2 kertas tidak dapat dihisap dengan pipa-pipa penghisap}

Penyebab :

a. Angin penghembus teralu kecil.

b. Angin penghisap terlalu kecil.

c. Meja penumpukan kertas terlalu rendah.

d. Kertas lengket (kurangnya kocokan/kibasan angin).

e. Pipa penghisap tersumbat debu kertas.

f. Karet vakum cacat.

2.3 Jalan lembaran kertas pada meja penghantar (meja infeed) miring

Penyebab :

a. Angin penghisap meja penghantar (meja infeed) kurang.

b. Angin penghisap (pick up sucker tidak seimbang antara kiri dan kanan.

c. Tekanan roda karet dan roda sikat penghantar kertas tidak seimbang.

d. Hisapan Pipa penghisap tidak sama antara kanan dan kiri.

e. Tekanan lidah penahan kertas tidak sama antara kanan dan kiri.

f. Pada saat pemasukan, letak palet miring.

g. Karet vakum cacat.
2.4 Kertas melengkung pada saat jalan di meja penghantar

Penyebab :

a. Tekanan roda penghantar kertas pada meja aparat terlalu berat.

b. Hembusan angin penghembus terlalu kencang.

c. Kertas bergelombang.

\subsection{Tarikan penepat samping (side lay)} tidak stabil

Penyebab :

a. Potongan kertas tidak rata/tidak siku

b. Jarak tarikkan kertas terlalu jauh

\subsection{Kertas Keriput}

Penyebab :

a. Kertas lembab, yang mengakibatkan kertas bergelombang

b. Jepitan kertas pada gripper tanggung

3. Mengatasi Masalah yang Terkait pada Transportasi Kertas di Mesin KOMORI LITHRONE G40

\subsection{Lembar kertas sering terhisap ganda}

Solusi :

a. Menambahkan angin penghembus sampai dapat memisahkan kertas dengan baik lembar demi lembar pada tumpukan kertas.

b. Menyetel lidah penahan kertas sedikit lebih jauh ke dalam tumpukan kertas. 
c. Menyetel ketinggian penumpukan kertas $0,5 \mathrm{~cm}$ lebih rendah dari batas atas ketinggian tumpukan kertas.

3.2 Kertas tidak dapat dihisap dengan pipa-pipa penghisap

Solusi :

a. Tambah angin penghembus sampai tumpukan kertas bagian atas telihat terpisah satu dengan yang lain.

b. tambah angin penghisap sedikit demi sedikit sampai hanya dapat menghisap 1 lembar kertas.

c. Mengatur kembali meja penumpukan kertas sampai kurang lebih $0,5 \mathrm{~cm}$ dari permukaan penata kertas.

d. Pada saat pemberian angin (pengkibasan kertas), pastikan lembar demi lembar kertas telah terpisah.

e. Bersihkan pipa penghisap kertas dengan air gun.

f. Ganti karet vakum.

3.3 Jalan lembaran kertas pada meja penghantar (meja infeed) miring

Solusi :

a. Menambahkan daya hisap pada meja infeed

b. Mengurangi tekanan roda karet dan roda sikat penghantar kertas secara manual.

c. Menyeimbangkan daya hisap antara pipa penghisap kanan dan kiri. d. Menyeimbangkan tekanan antara kanan dan kiri lidah penahan kertas.

e. Membetulkan posisi palet.

f. Mengganti dengan karet vakum yang baru.

\subsection{Kertas melengkung pada saat jalan di} meja penghantar (meja infeed)

Solusi :

a. Menyetel tekanan roda karet dan roda sikat penghantar kertas.

b. Mengurangi kekuatan angin pada angin penghembus.

\subsection{Tarikan penepat samping (side lay)} tidak stabil

Solusi :

a. Pemotong ulang kertas atau gunakan kertas yang dipotong dengan benar.

b. Menyetel ulang tarikan kertas pada penepat samping $\pm 0,5 \mathrm{~cm}$.

\subsection{Kertas keriput}

Solusi :

a. Pada saat penyimpanan, kertas harus disimpan pada ruangan dengan suhu udara yang pas, yaitu $28 \mathrm{cc}$.

Pada saat menumpuk kertas di meja pemasukan, posisi kertas di paskan pada jepitan gripper, dan juga memperhatikan tarikan kertas pada penepat samping (side lay). 


\section{KESIMPULAN}

Untuk tercapainya kelancaran pada proses pencetakan, maka berkaitan erat dengan transportasi kertas yang baik. Agar mendapatkan transportasi tanpa kendala hal utama yang perlu dilakukan adalah penyetelan yang tepat pada komponenkomponen unit pemasukan. Apabila kelancaran transportasi kertas telah didapatkan, maka operator dapat lebih berfokus untuk mencapai ketepatan cetak pada hasil cetakan. Berikut kesimpulan yang didapat oleh penulis :

1. Proses pencetakan yang baik akan didapat apabila transportasi kertas telah berjalan dengan lancar. Kelancaran jalannya kertas sangat bergantung pada penyetelan unit pemasukan (feeder unit). Apabila transportasi kertas telah berjalan lancar maka akan meminimalisir gangguan cetak lainnya, maka dari itu beberapa komponen yang harus sangat diperhatikan penyetelannya sebagai berikut : penyetelan pada meja konsul, penyetelan pada meja penumpukan, mengatur penahan kertas samping (jogger), menyetel kepala hisap (suction head), memeriksa angin penghembus, menyetel alat peraba ketinggian kertas, menyetel lidah pemisah lembaran kertas, menyetel penghisap dan pengangkat lembaran kertas (sucker dan forwarding sucker), menyetel roda penghantar kertas, menyetel pencegah kertas rangkap (double sheet detector), menyetel penepat samping (side lay).

2. Seorang operator harus mengetahui permasalahan dan penyebab yang membuat kelancaran transportasi kertas menjadi terhambat, masalah yang sering terjadi pada transportasi kertas yaitu : pengaturan penepat samping (side lay) tidak menarik kertas atau menarik keras terlalu banyak, kekuatan angin penghembus dan penghisap yang terlalu kuat atau terlalu lemah, roda aparat yang terlalu menekan dan kekuatan hisapan angin pada karet penghantar kertas terlalu lemah.atau terlalu kuat, pencegah kertas rangkap (double sheet detector) membaca kertas selalu rangkap atau kertas rangkap dapat lolos, jalannya kertas miring pada saat berjalan di meja aparat (meja infeed), ujung kertas melengkung karena tekanan angin penghembus terlalu besar.

3. Seorang operator selain harus mampu mengetahui permasalahan dan kendala yang terjadi selama proses pencetakan berlangsung, operator juga haruslah mengetahui penanggulangan masalah yang terjadi pada mesin cetak, itu sebabnya sangat penting untuk dilakukan seminar-seminar untuk dapat 
mengetahui permasalahan dan penanggulangan dari mesin yang ditanganinya.

Apabila seorang operator tidak mampu mengatasi masalah yang terjadi maka akan mengganggu proses jalannya produksi yang mengakibatkan kerugian waktu dan pendapatan yang seharusnya didapat oleh perusahaan.

\section{Saran}

Dari beberapa hal yang terjadi selama proses produksi cetak, penyebab kurang baiknya penyetelan komponen-komponen pada transportasi kertas disebabkan kurang telitinya seorang operator dalam mengatur komponen-komponen pada bagian unit pemasukan (feeder unit) pada mesin cetak ofset lembaran yang dapat mengganggu proses pencetakan yang dapat berpengaruh terhadap tercapainya ketepatan cetak dari hasil cetakan, maka penulis memaparkan beberapa saran, berupa :

1. Perlunya diterapkan standarisasi penyetelan setiap komponen-komponen unit pemasukan (feeder unit) karena dapat sangat mempengeruhi kelancaran transportasi kertas yang juga memiliki pengaruh terhadap upaya mencapai ketepatan cetak yang maksimal.

2. Untuk meminimalisir kerusakan yang terjadi terhadap penggunaan bahan baku, maka perlu diadakannya perawatan mesin rutin secara berkala, karena kelancaran jalannya transportasi kerjas juga dipengaruhi oleh kondisi mesin. Apabila mesin dalam keadaan baik, maka penyetelan tidak akan sulit untuk dilakukan.

3. Seorang operator harus mampu memahami permasalahan dan upaya untuk mengatasi masalah yang terjadi saat permasalahan terjadi pada saat pencetakan berlangsung.

1. Perlunya diadakan seminar dan pelatihan pada setiap operator mesin cetak ofset agar dapat memudahkan operator dalam memahami dan menyelesaikan permasalahan yang terjadi pada saat pencetakan berlangsung.

\section{REFERENSI}

Djaiz, Mukhyidin. 2010. Buku Ajar Pengantar Ilmu Grafika. Jakarta: Politeknik Negeri Media Kreatif.

Raharjo, Sugio. 2016. Sejarah Gramedia Printing. PT. Gramedia Printing Cikarang Plant.

Soebardianto. 2018. Buku Ajar Mata Kuliah

Cetak Ofset. Jakarta; Politeknik Negeri Media Kreatif.

Sudiyamto. 2011. Teori Dasar Cetak Ofset. Jakarta; Politeknik Negeri Media Kreatif. 
Vol. 6, No. 1, April 2019, hal. 42-61

Wasono, Bowo Antonius. 2008. Teknik Wulan,Widya Retno. 2018. "Laporan Praktik Grafika dan Industri Grafika Jilid 2. Industri di PT. Gramedia Printing PT. Gramedia Pinting. Cikarang Plant.” Jakarta. 